\title{
Analysis of temperature changes and sterilization effect of diode laser for the treatment of peri-implantitis by wavelength and irradiation time
}

\author{
Jeong-Hwan Seol', Jun Jae Lee', Kee-Yeon Kum², Jong-Ho Lee ${ }^{3}$, Young-Joon Lim* \\ 'Department of Prosthodontics, School of Dentistry, Seoul National University, Seoul, Republic of Korea \\ 'Department of Conservative Dentistry and Dental Research Institute, Seoul National University, Seoul, Republic of Korea \\ ${ }^{3}$ Department of Oral and Maxillofacial Surgery, Clinical Trial Center, Seoul National University, Seoul, Republic of Korea
}

Purpose: We compared the effects of newly developed diode laser (Bison $808 \mathrm{~nm}$ Diode laser) on the treatment of peri-implantitis with conventional products (Picasso $810 \mathrm{~nm}$ Diode laser) by comparing the surface temperature of titanium disc and bacterial sterilization according to laser power. Materials and Methods: The titanium disc was irradiated for 60 seconds and $1-2.5 \mathrm{~W}$ using diode laser $808 \mathrm{~nm}$ and $810 \mathrm{~nm}$. The surface temperature of the titanium disc was measured using a temperature measurement module and a temperature measurement program. In addition, in order to investigate the sterilizing effect according to the laser power, $808 \mathrm{~nm}$ laser was irradiated after application of bacteria to sandblasted large-grit acid-etched (SLA) and resorbable blast media (RBM) coated titanium discs. The irradiated disks were examined with scanning electron microscopy. Results: Both 808 $\mathrm{nm}$ and $810 \mathrm{~nm}$ lasers increased disk surface temperature as the power increased. When the $810 \mathrm{~nm}$ was irradiated under all conditions, the initial temperature rise rate, the descending rate, and the temperature change before and after was higher than that of $808 \mathrm{~nm}$. Disk surface changes were not observed on both lasers at all conditions. Bacteria were irradiated with $808 \mathrm{~nm}$, and the bactericidal effect was increased as the power increased. Conclusion: When applying these diode lasers to the treatment of peri-implantitis, $808 \mathrm{~nm}$ which have a bactericidal effect with less temperature fluctuation in the same power conditions would be considered safer. However, in order to apply a laser treatment in the dental clinical field, various safety and reliability should be secured. (J Dent Rehabil Appl Sci 2017;33(3):178-88)

Key words: peri-implantitis; diode laser; bacteria; titanium; temperature change

\begin{abstract}
서론
지난 세기 동안 임플란트 주위염 치료를 위해 사용되 고 있던 기계식 절삭 장치의 경우, 점점 크기가 작아지고 효율성이 증가하고 있으나 기계의 진동 및 소음으로 인 한 환자의 공포감 유발 등의 문제로 인해 20세기 후반에 들면서 이를 개선하기 위한 대안 방안으로 레이저를 이 용한 치료들이 주목 받고 있다. ${ }^{1}$
\end{abstract}

레이저는 기계식 절삭장치와는 달리 조직에 마멸, 지혈 및 정화 효과가 복합적, 동시적으로 작용 치주 치료에 적 용된다. 또한 소음과 진동이 미비하여 환자의 심리적 안 정감을 증가시키며, 정확한 절개 및 주변 조직에 대한 최 소한의 손상 발생으로 인해 처치 후 통증이 적으며 예후 가 좋다는 장점이 있다. ${ }^{1}$ 이러한 장점을 바탕으로 최근 임플란트 영역에서 레이저 사용에 대한 연구가 활발하게 이루어지고 있다. 임상적 적용이 가능한 이상적인 레이

Copyright@ 2017 The Korean Academy of Stomatognathic Function and Occlusion. (c) It is identical to Creative Commons Non-Commercial License. 
저는 주위조직에 열손상을 최소로 하고 혈관을 응고시켜 정확한 시술을 가능하게 하며 임플란트 주위염 치료 시 육아조직을 정확히 제거할 수 있어야 한다. ${ }^{2,3}$

임플란트 주위염은 미생물 감염에 의한 염증성 질환으 로 임플란트를 지지하는 골의 소실을 동반하며 임플란트 주위에 미생물의 침착으로 인해 발생하는 염증반응이 주 요 병인으로 알려져 있다. ${ }^{3-6}$ 현재, 임플란트 주위의 미생 물 침착을 제거 하는 방법 등이 연구되고 있으나, ${ }^{7,8}$ 오염 된 임플란트 표면을 정화하여 임플란트 주위 조직의 건 강을 회복하는 이상적인 방법에 대해서는 아직 명확한 기준이 확립되지 않았다. ${ }^{9}$ 최근에, 여러 연구들을 통해 티 타늄 임플란트에 레이저를 사용하여 표면을 살균, 정화 시키는 방법에 대한 실험이 많이 보고되고 있으며, 이로 인해 임플란트 주위염 치료에 있어서 레이저 조사의 잠재 적인 효과가 주목을 받고 있는 추세이다. ${ }^{10-12}$ 하지만, 레 이저 조사 시 과도한 온도상승이 임플란트 주변 조직의 괴사를 유발한다는 보고는 있으나, ${ }^{13}$ 레이저 출력에 따른 임플란트 주변 온도 변화에 따른 연구는 아직 미흡한 실 정이다.

이에, 본 연구는 임플란트 주위염 치료에 사용하도 록 개발한 Bison $808 \mathrm{~nm}$ Diode laser (Bison Medical Co., Seoul, Korea)와 현재 치과 진료에 이용 되고 있는 Picasso $810 \mathrm{~nm}$ Diode laser (Dentsply international, Sarasota, USA)를 in vitro 상에서 티타늄 디스크에 조사 하여, 조사 시간에 따른 온도 상승 및 공랭 조건에서 온 도 하강 정도를 비교하고 그 차이를 분석하였다. 또한 E.coli bacteria를 배양한 디스크에 Bison $808 \mathrm{~nm}$ Diode laser를 조사하여 살균효과를 확인하고, Bioson $808 \mathrm{~nm}$ Diode laser의 임상적용 가능성을 평가하고자 하였다.

\section{연구 재료 및 방법}

B808 (Bison $808 \mathrm{~nm}$ Diode laser)와 P810 (Picasso 810 $\mathrm{nm}$ Diode laser)을 사용하여 티타늄 디스크 $(\phi 10 \mathrm{~mm} \times$ $5 \mathrm{~mm}$ )에 60초 동안 $1-2.5 \mathrm{~W}$ 의 출력조건으로 레이저를 조사하였다. 디스크 표면온도 측정을 위해 E.bloxxA4-1 (Gantner Inc., San Diego, USA), 8739140000 (weidmuller, Detmold, Germany) 및 Ex9530 (Expert Daq, Düsseldorf, Germany)의 통합 모듈과 Signa soft (Index $\mathrm{TM}$, Yongin, Korea) 온도 측정 프로그램을 이용하여 온 도 변화를 1 초 간격으로 기록하였다.

\section{Measurement of temperature}

디스크 표면에 60 초 동안 다이오드 레이저를 조사하여 온도변화를 측정하였다. 조사 시간에 따른 온도 변화를 관찰하기 위해, 처음 60 초동안 레이저를 조사하며 온도 상승을 실시간으로 측정하였다. 그 후 60 초간 서서히 공 랭시키며 디스크 표면의 온도 감소 정도를 측정하였다. 레이저 조사 시간은 이전에 발표된 논문들의 시간 조건 인 10초 - 30 초 조건보다 길게 설정하였다. ${ }^{10-12}$ 레이저는 연속 모드로 실행 하였으며, 출력은 $1 \mathrm{~W}, 1.5 \mathrm{~W}, 2 \mathrm{~W}, 2.5$ $\mathrm{W}$ 로 설정 하였다. ${ }^{13}$ 실험은 각 조건 별 10 회 실시하였으 며, 결과의 평균값을 분석 하였다.

\section{Analysis of disk surface morphology by laser irradiation}

Diode laser의 출력 및 온도 변화에 따른 디스크의 표 면상태의 변화를 관찰하기 위하여 주사전자현미경(Field Emission Scanning Electron Microscope; FE-SEM, S-4700, HITACHI, Tokyo, Japan)을 이용하여 디스크의 표면을 관찰하였다.

\section{Sterilizing effect of Bison $808 \mathrm{~nm}$ Diode laser}

B808의 살균 효과를 확인하기 위하여, 디스크를 sandblasted large-grit acid-etched (SLA)방식과 resorbable blast media (RBM)방식을 통해 표면처리를 실행한 후, 임플란트 주위염 발생의 주요 원인중 하나인 치면 세균 막 형성에 주요한 역할을 하는 세균인 Porphyromonas gingivalis와 유사한 그람 음성균 ${ }^{14-16}$ E.coli DH5 $\alpha$ (invitrogen, Carlsbad, USA) 박테리아를 LB Broth (SigmaAldrich, St. Louis, USA) 배지에서 $37^{\circ} \mathrm{C}$ 로 5일간 shaking incubator에서 배양하여 표면에 코팅하였다. ${ }^{17-19}$ 박테 리아를 코팅한 디스크를 30 분간 클린벤치에서 건조시킨 뒤, 레이저 출력을 $0.5 \mathrm{~W}, 1 \mathrm{~W}, 2 \mathrm{~W}, 3 \mathrm{~W}$ 로 설정하여 각 각 30 초간 디스크 4 군데에 조사하였다. 디스크표면의 상 태확인을 위해 FE-SEM 촬영을 실시하였고, FE-SEM 장비의 부가적 장치인 Energy Dispersive Spectrometry (EDS)를 이용하여 디스크 표면의 탄소함유량 측정을 실 시하였다. 


\section{Statistical analysis}

초기 온도 상승, 하강 속도 및, 측정 전후 상승, 하강 온 도를 출력에 따라 계산하였다. 그 후, Sigmaplot (Systat Soft Ware Inc., San Jose, USA) 프로그램을 이용하여 one way ANOVA 분석을 하였으며 다자간 분석은 Student-Newman-Keuls Method로 비교하였다 $(P<0.05)$.

\section{결과}

\section{Analysis for increment of surface temperature}

1) The temperature increment trend of B808 (Bison $808 \mathrm{~nm}$ diode laser)

B808을 사용하여 디스크에 다양한 출력조건(1 W - 2.5 W)으로 60 초 동안 조사하면서 디스크 표면의 온도 변화 를 실시간으로 수집한 결과를 Fig. $1 \mathrm{~A}$ 에 나타내었다. 1 $\mathrm{W}$ 출력의 경우 시간이 경과 함에 따라, $\mathrm{T}\left({ }^{\circ} \mathrm{C}\right)=0.9308$ $\times \ln \{$ time $(\mathrm{sec})\}+26.20\left({ }^{\circ} \mathrm{C}\right)\left(\mathrm{R}^{2}=0.8737, \mathrm{n}=10\right)$ 의 형태로 온도가 증가하였다. $1.5 \mathrm{~W}$ 출력의 경우 시간 이 경과 함에 따라, $\mathrm{T}\left({ }^{\circ} \mathrm{C}\right)=1.8856 \times \ln \{$ time $(\mathrm{sec})\}+$ $23.93\left({ }^{\circ} \mathrm{C}\right)\left(\mathrm{R}^{2}=0.899, \mathrm{n}=10\right)$ 의 형태로 온도가 증가하 였다. $2 \mathrm{~W}$ 출력의 경우 시간이 경과 함에 따라, $\mathrm{T}\left({ }^{\circ} \mathrm{C}\right)=$ $2.3774 \times \ln \{\operatorname{time}(\mathrm{sec})\}+25.56\left({ }^{\circ} \mathrm{C}\right)\left(\mathrm{R}^{2}=0.9078, \mathrm{n}=\right.$ 10)의 형태로 온도가 증가하였다. $2.5 \mathrm{~W}$ 출력의 경우 시 간이 경과 함에 따라, $\mathrm{T}\left({ }^{\circ} \mathrm{C}\right)=3.1107 \times \ln \{\mathrm{time}(\mathrm{sec})\}+$ $23.35\left({ }^{\circ} \mathrm{C}\right)\left(\mathrm{R}^{2}=0.874, \mathrm{n}=10\right)$ 의 형태로 온도가 증가하 였다. 조사 시간이 증가함에 따라 온도가 높아졌고, 출력 이 증가함에 따라 온도의 증가 폭이 커지는 것을 확인하 였다.

2) The temperature increment trend of P810 (Picasso $810 \mathrm{~nm}$ diode laser)

Fig. 1B에 P810을 사용하여 디스크에 B808과 같은 출 력조건으로 60 초 동안 조사하면서 디스크 표면의 온도 변화를 실시간으로 측정한 결과를 나타내었다. $1 \mathrm{~W}$ 출 력의 경우, $\mathrm{T}\left({ }^{\circ} \mathrm{C}\right)=2.3234 \times \ln \{\mathrm{time}(\mathrm{sec})\}+23.62\left({ }^{\circ} \mathrm{C}\right)$ $\left(\mathrm{R}^{2}=0.8937, \mathrm{n}=10\right)$ 의 형태로 온도가 증가하였으며, 1.5 W의 경우, $\mathrm{T}\left({ }^{\circ} \mathrm{C}\right)=3.6916 \times \ln \{\mathrm{time}(\mathrm{sec})\}+23.27\left({ }^{\circ} \mathrm{C}\right)\left(\mathrm{R}^{2}\right.$ $=0.9437, \mathrm{n}=10)$ 으로 증가하였고 $2 \mathrm{~W}$ 출력에서는 $\mathrm{T}\left({ }^{\circ} \mathrm{C}\right)$ $=4.7676 \times \ln \{$ time $(\mathrm{sec})\}+21.29\left({ }^{\circ} \mathrm{C}\right)\left(\mathrm{R}^{2}=0.9008, \mathrm{n}\right.$ = 10)의 형태로 온도가 증가하였다. $2.5 \mathrm{~W}$ 의 출력에서
는 $\mathrm{T}\left({ }^{\circ} \mathrm{C}\right)=4.9832 \times \ln \{\operatorname{time}(\mathrm{sec})\}+22.00\left({ }^{\circ} \mathrm{C}\right)\left(\mathrm{R}^{2}=\right.$ $0.9268, \mathrm{n}=10)$ 의 형태로 온도가 증가하였다. B808의 결 과와 같이 조사 시간과 출력이 증가함에 따라 온도 변화 폭은 늘어났으며 P810이 B808보다 더 높은 온도 변화율 을 보였다.

3) The initial temperature change by laser power

Diode laser 조사 시작 후 처음 5 초 동안의 온도 변화 량을 이용하여 초기 온도상승 속도를 계산하여 Fig. 1 (C)에 나타내었다. 각 출력당 $\mathrm{B} 808$ 의 초기 온도 상승 속 도의 경우, $1 \mathrm{~W}=0.06 \pm 0.01^{\circ} \mathrm{C} / \mathrm{sec}, 1.5 \mathrm{~W}=0.24 \pm$ $0.03^{\circ} \mathrm{C} / \mathrm{sec}, 2 \mathrm{~W}=0.39 \pm 0.07^{\circ} \mathrm{C} / \mathrm{sec}$ 그리고 $2.5 \mathrm{~W}$ 의 경우 $0.27 \pm 0.04^{\circ} \mathrm{C} / \mathrm{sec}$ 의 초당 온도 상승이 일어났다. $\mathrm{P} 810$ 의 각 출력당 초기 온도상승 속도 측정 결과, $1 \mathrm{~W}=$ $0.29 \pm 0.10^{\circ} \mathrm{C} / \mathrm{sec}, 1.5 \mathrm{~W}=0.57 \pm 0.05^{\circ} \mathrm{C} / \mathrm{sec}, 2 \mathrm{~W}=$ $0.58 \pm 0.03^{\circ} \mathrm{C} / \mathrm{sec}$ 그리고 $2.5 \mathrm{~W}=0.99 \pm 0.08^{\circ} \mathrm{C} / \mathrm{sec}$ 의 초당 온도 상승을 관찰할 수 있었다. 두 가지 장치 모 두에서 출력이 높아짐에 따라 온도상승 속도가 커지는 것을 확인할 수 있었다.

4) Temperature change range by laser power

Diode laser를 60초간 조사한 뒤 측정된 온도와 시작 온도의 차이를 구하여 얻은 온도 증가폭을 Fig. 1D에 나 타내었다. B808의 경우, $1 \mathrm{~W}$ 출력에서 시작온도는 27.3 $\pm 0.32^{\circ} \mathrm{C}$ 였으며, 60 초 경과 후 $30.4 \pm 0.26^{\circ} \mathrm{C}$ 로 온도 증 가 폭은 $3.1 \pm 0.07^{\circ} \mathrm{C}$ 였다. $1.5 \mathrm{~W}$ 의 시작온도는 $26.0 \pm$ $1.09^{\circ} \mathrm{C}$ 였으며, 60 초 경과 후 $32.4 \pm 0.95^{\circ} \mathrm{C}$ 로 $6.3 \pm 0.28^{\circ} \mathrm{C}$ 상승하였다. $2 \mathrm{~W}$ 에서는 시작온도가 $27.4 \pm 0.72^{\circ} \mathrm{C}$ 였으며, 60 초 경과 후 $36.3 \pm 1.43^{\circ} \mathrm{C}$ 로 온도가 $8.3 \pm 0.45^{\circ} \mathrm{C}$ 상승하 였다. $2.5 \mathrm{~W}$ 출력의 경우 시작온도는 $26.9 \pm 0.16^{\circ} \mathrm{C}$ 였으며, 60 초 경과 후 $37.8 \pm 0.27^{\circ} \mathrm{C}$ 로 온도가 $10.6 \pm 0.11^{\circ} \mathrm{C}$ 상 승하였다. 출력량이 높아짐에 따라 온도의 증가폭도 커 지는 것을 확인할 수 있었다.

$\mathrm{P} 810$ 의 경우, $1 \mathrm{~W}$ 의 시작온도는 $26.0 \pm 0.22^{\circ} \mathrm{C}$ 였으며 60 초 조사 후 $34.4 \pm 1.52^{\circ} \mathrm{C}$ 로 $8.3 \pm 0.78^{\circ} \mathrm{C}$ 온도가 상승 하였다. $1.5 \mathrm{~W}$ 의 시작온도는 $26.9 \pm 0.37^{\circ} \mathrm{C}$ 였고 60 초 경 과 후 $39.9 \pm 1.72^{\circ} \mathrm{C}$ 로 $13.0 \pm 1.19^{\circ} \mathrm{C}$ 의 온도 상승이 발생 했다. $2.0 \mathrm{WW}$ 출력의 경우 시작온도는 $26.9 \pm 0.28^{\circ} \mathrm{C}$ 였으 며, 60 초 경과 후, $43.2 \pm 0.48^{\circ} \mathrm{C}$ 로 온도가 $16.3 \pm 0.40^{\circ} \mathrm{C}$ 상 승하였다. $2.5 \mathrm{~W}$ 출력의 경우 시작온도는 $25.9 \pm 0.32^{\circ} \mathrm{C}$ 였으 며, 60 초 경과 후, $44.6 \pm 1.20^{\circ} \mathrm{C}$ 로 온도가 $18.3 \pm 0.80^{\circ} \mathrm{C}$ 상승하였다. B808과 비교하여 P810이 모든 출력 조건에 
A

$808 \mathrm{~nm}$ Diode laser

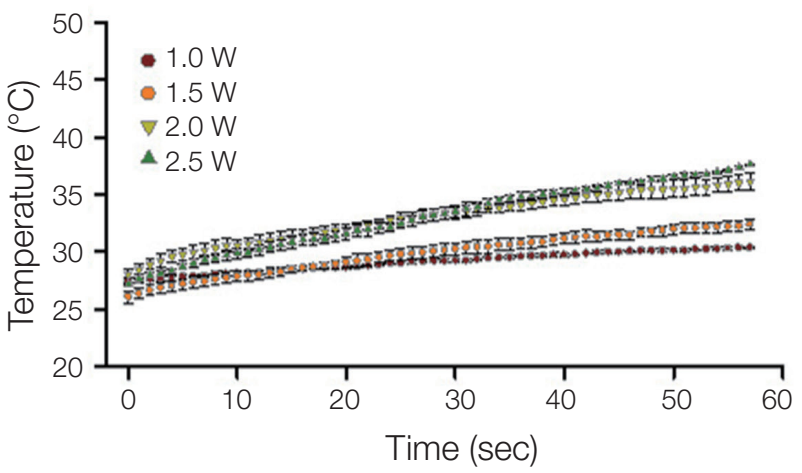

C

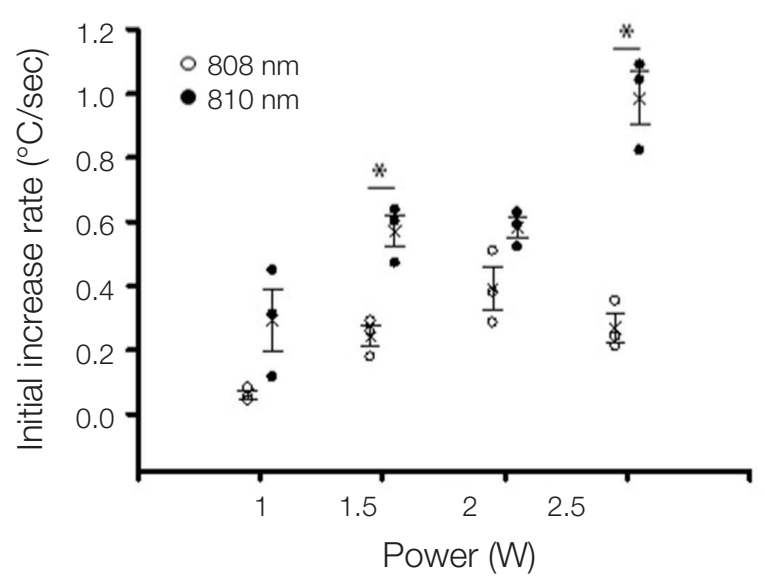

B

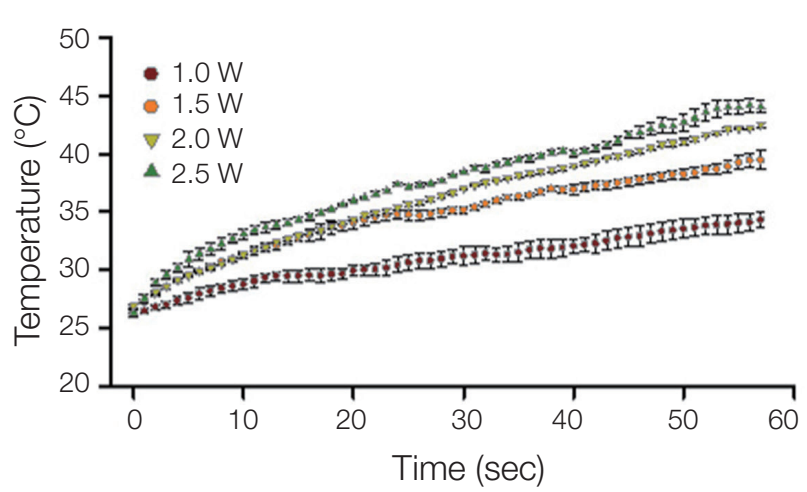

D

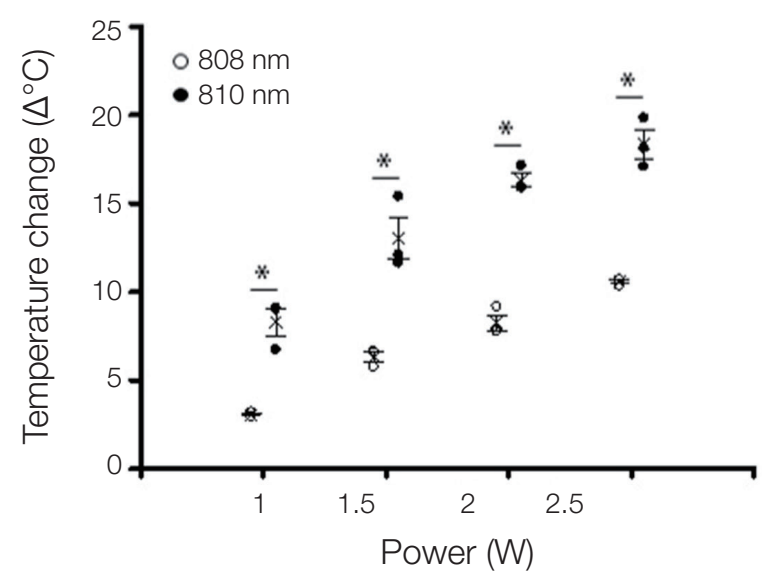

Fig. 1. Analysis for increment of disc temperature by conditions of laser. (A) Temperature increment trend of B808. (B) Temperature increment trend P810. $\bullet 1 \mathrm{~W}, \bullet ; 1.5 \mathrm{~W}, \nabla ; 2 \mathrm{~W}, \Delta ; 2.5 \mathrm{~W}(\mathrm{n}=5)$. (C) Initial temperature change by laser power. (D) Temperature change range by laser power. O; B808. • P810. $* P<0.05$.

서 온도 증가 폭이 컸으며 레이저 조사 후 높은 표면 온 도를 나타내었다.

\section{Analysis for decrement of temperature}

1) The temperature decrement trend of Bison 808 $\mathrm{nm}$ Diode laser

B808을 사용하여 디스크에 laser를 60초간 조사한 후, 60 초간 서서히 공랭시키면서 disc 표면의 온도변화를 1 초 간격으로 수집한 결과를 Fig. 2A에 나타내었다.

$1 \mathrm{~W}$ 출력의 경우 시간이 경과 함에 따라, $\mathrm{T}\left({ }^{\circ} \mathrm{C}\right)=$ $-0.444 \times \ln \{$ Time $(\mathrm{sec})\}+30.87\left({ }^{\circ} \mathrm{C}\right)\left(\mathrm{R}^{2}=0.8422, \mathrm{n}=3\right)$ 의 형태로 온도가 감소하였다. $1.5 \mathrm{~W}$ 출력에서는 $\mathrm{T}\left({ }^{\circ} \mathrm{C}\right)=$
$-1.006 \times \ln \{$ Time $(\mathrm{sec})\}+35.56\left({ }^{\circ} \mathrm{C}\right)\left(\mathrm{R}^{2}=0.8905, \mathrm{n}=\right.$ 3)로 온도가 감소하였으며, $2 \mathrm{~W}$ 출력은 $\mathrm{T}\left({ }^{\circ} \mathrm{C}\right)=-1.282$ $\times \ln \{\operatorname{Time}(\mathrm{sec})\}+36.93\left({ }^{\circ} \mathrm{C}\right)\left(\mathrm{R}^{2}=0.9653, \mathrm{n}=3\right)$ 로 온 도가 감소하였고, $2.5 \mathrm{~W}$ 출력에서는 $\mathrm{T}\left({ }^{\circ} \mathrm{C}\right)=-1.496 \times$ $\ln \{$ Time $(\mathrm{sec})\}+39.26\left({ }^{\circ} \mathrm{C}\right)\left(\mathrm{R}^{2}=0.8794, \mathrm{n}=3\right)$ 의 형태 로 온도가 감소하는 것을 확인하였다. 출력이 높아짐에 따라 온도 감소폭이 높은 것을 확인하였다.

2) The temperature decrement trend of Picasso 810 nm Diode laser

P810를 사용하여 디스크에 laser를 60초간 조사한 후, 60 초간 공랭시키며 얻은 온도 변화 그래프를 Fig. 2B에 나타내었다. 
$1 \mathrm{~W}$ 출력의 경우 시간이 경과 함에 따라, $\mathrm{T}\left({ }^{\circ} \mathrm{C}\right)=$ $-1.168 \times \ln \{\operatorname{Time}(\mathrm{sec})\}+34.82\left({ }^{\circ} \mathrm{C}\right)\left(\mathrm{R}^{2}=0.9603, \mathrm{n}=\right.$ 3)의 형태로 온도가 감소하였다. $1.5 \mathrm{~W}$ 는 $\mathrm{T}\left({ }^{\circ} \mathrm{C}\right)=-1.419$ $\times \ln \{\operatorname{Time}(\mathrm{sec})\}+40.46\left({ }^{\circ} \mathrm{C}\right)\left(\mathrm{R}^{2}=0.8962, \mathrm{n}=3\right)$ 의 형 태로 온도가 감소하였으며 $2 \mathrm{~W}$ 출력의 경우에는 $\mathrm{T}\left({ }^{\circ} \mathrm{C}\right)$ $=-1.886 \times \ln \{$ Time $(\mathrm{sec})\}+44.27\left({ }^{\circ} \mathrm{C}\right)\left(\mathrm{R}^{2}=0.9148, \mathrm{n}=\right.$ 3)의 형태로 온도가 감소하였고 $2.5 \mathrm{~W}$ 출력에서는 $\mathrm{T}\left({ }^{\circ} \mathrm{C}\right)$ $=-2.358 \times \ln \{$ Time $(\mathrm{sec})\}+45.42\left({ }^{\circ} \mathrm{C}\right)\left(\mathrm{R}^{2}=0.9465, \mathrm{n}\right.$ $=3)$ 의 형태로 온도가 감소하였다. 레이저의 출력이 높고 최종 온도가 높은 경우 온도 하강 속도가 높아지는 것을 확인하였다.

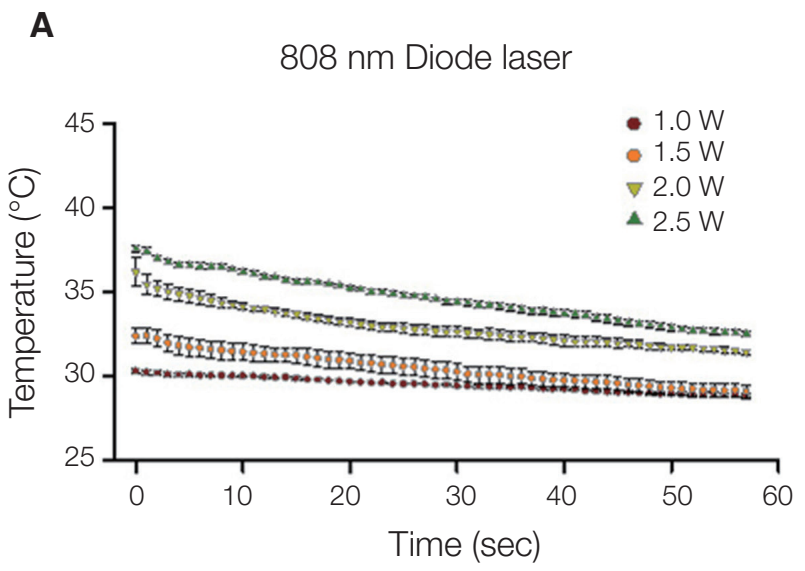

\section{C}

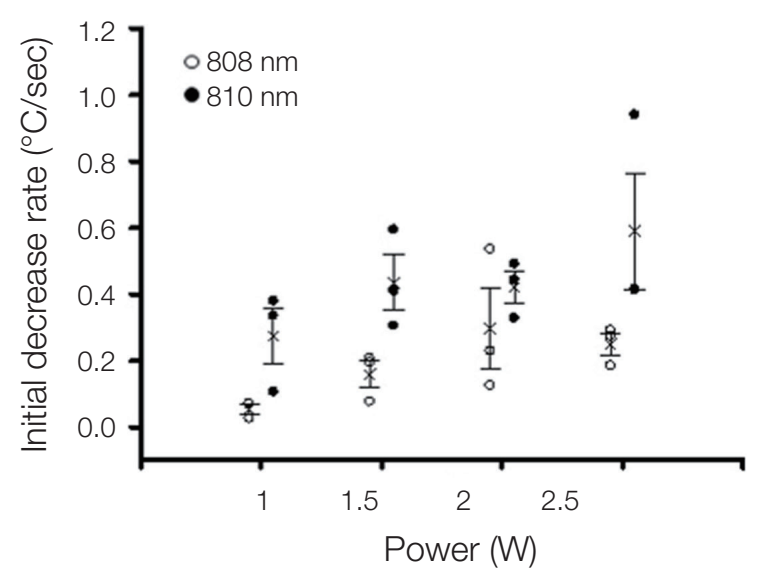

3) The initial temperature change by laser power

Diode laser를 사용하여 디스크에 레이저를 60초간 조 사한 후, 공랭을 시작한 5 초동안의 온도 변화량을 이용 하여 온도 하강 속도를 계산한 그래프를 Fig. 2C에 나타 내었다.

$\mathrm{B} 808$ 의 초기 온도 하강 속도는 $1 \mathrm{~W}=0.05 \pm 0.01^{\circ} \mathrm{C} /$ sec, $1.5 \mathrm{~W}=0.16 \pm 0.04^{\circ} \mathrm{C} / \mathrm{sec}, 2 \mathrm{~W}=0.30 \pm 0.12^{\circ} \mathrm{C} /$ $\mathrm{sec}$ 그리고 $2.5 \mathrm{~W}=0.25 \pm 0.03^{\circ} \mathrm{C} / \mathrm{sec}$ 의 초당 온도 하 강이 일어났다.

$\mathrm{P} 810$ 의 초기 온도 하강 속도를 계산한 결과, $1 \mathrm{~W}=$ $0.27 \pm 0.08^{\circ} \mathrm{C} / \mathrm{sec}, 1.5 \mathrm{~W}=0.44 \pm 0.08^{\circ} \mathrm{C} / \mathrm{sec}, 2 \mathrm{~W}=$

\section{B}

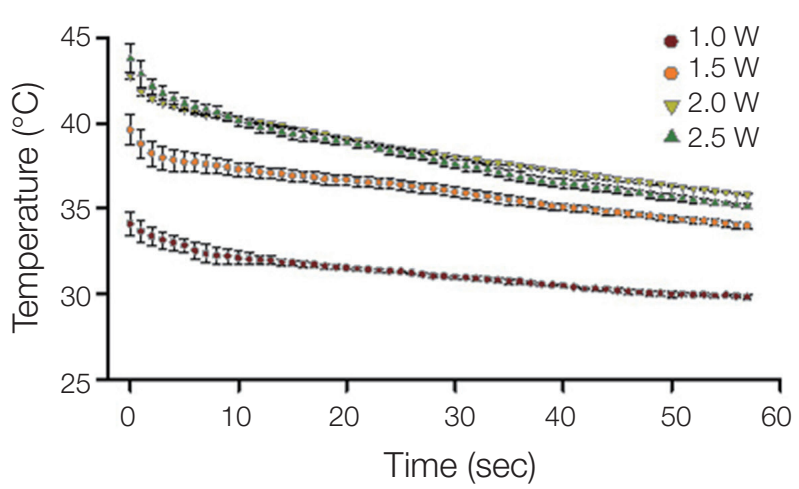

D

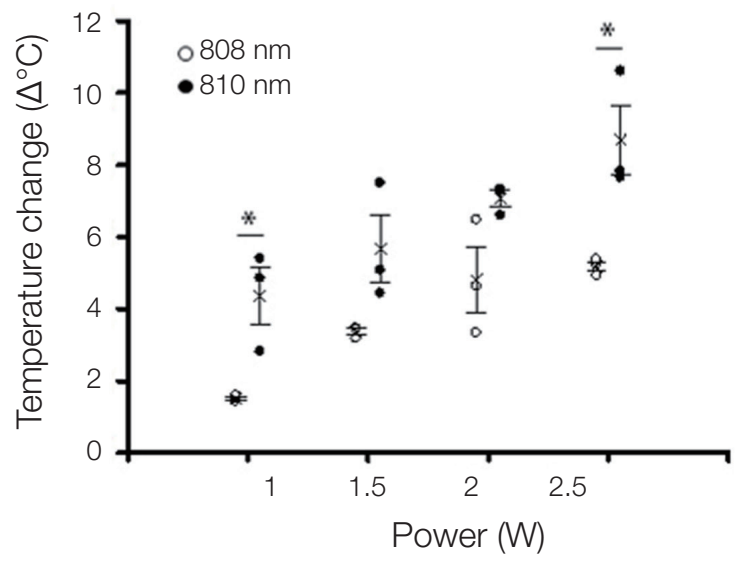

Fig. 2. Analysis for decrement of disc temperature by conditions of laser. (A) Temperature decrement trend of B808. (B) Temperature decrement trend of P810. $\bullet 1 \mathrm{~W}, \bullet ; 1.5 \mathrm{~W}, \nabla ; 2 \mathrm{~W}, \Delta ; 2.5 \mathrm{~W}(\mathrm{n}=5)$. (C) Initial temperature change by laser power. (D) Temperature change range by laser power. O; B808. •; P810. * $P<0.05$. 
$0.42 \pm 0.05^{\circ} \mathrm{C} / \mathrm{sec}$, 그리고 $2.5 \mathrm{~W}=0.59 \pm 0.18^{\circ} \mathrm{C} / \mathrm{sec}$ 의 초당 온도 하강이 일어났다. 하지만 B808과 P810 레 이저의 모든 조건을 분석하였을 때 통계적으로 유의한 차이를 보이지 않았다 $(P>0.05)$.

4) Temperature change range by laser power

Diode laser를 사용하여 디스크에 레이저를 60 초간 조 사한 디스크 표면의 최고 온도와 60 초간 공랭시킨 후 측 정한 온도를 비교하여 차이를 분석한 그래프를 Fig. $2 \mathrm{D}$ 에 나타내었다.

$\mathrm{B} 808$ 의 경우, $1 \mathrm{~W}$ 에서는 시작온도가 $30.4 \pm 0.33^{\circ} \mathrm{C}$, 공랭 60 초 경과 후 $28.8 \pm 0.24^{\circ} \mathrm{C}$ 로 온도가 $1.5 \pm 0.05^{\circ} \mathrm{C}$ 하 강하였다. $1.5 \mathrm{~W}$ 의 시작온도는 $32.4 \pm 0.98^{\circ} \mathrm{C}$ 였으며, 60 초 경과 후 $29.04 \pm 0.88^{\circ} \mathrm{C}$ 로 $3.4 \pm 0.09^{\circ} \mathrm{C}$ 하강하였으 며, $2 \mathrm{~W}$ 의 시작온도는 $36.4 \pm 1.60^{\circ} \mathrm{C}$ 였고, 60 초 경과 후 $31.4 \pm 0.26^{\circ} \mathrm{C}$ 로 $4.8 \pm 0.91^{\circ} \mathrm{C}$ 하강하였다. 그리고 2.5 $\mathrm{W}$ 의 경우 시작온도는 $37.8 \pm 0.27^{\circ} \mathrm{C}$ 였으며, 60 초 경과 후 $32.4 \pm 0.35^{\circ} \mathrm{C}$ 로 $5.2 \pm 0.13^{\circ} \mathrm{C}$ 하강한 것을 확인하였 다. 시작온도가 높을수록 하강 온도폭이 증가하는 것을 확인하였다.

$\mathrm{P} 810$ 레이저의 경우, $1 \mathrm{~W}$ 의 시작온도는 $34.4^{\circ} \mathrm{C} \pm$ 1.64 , 공랭 60 초 경과 후 온도는 $29.8 \pm 0.23^{\circ} \mathrm{C}$ 로 $4.4 \pm$ $0.79^{\circ} \mathrm{C}$ 하강하였다. $1.5 \mathrm{~W}$ 의 시작온도는 $39.9 \pm 1.76^{\circ} \mathrm{C}$ 였으며, 60 초 경과 후 $33.9 \pm 0.33^{\circ} \mathrm{C}$ 로 $5.7 \pm 0.93^{\circ} \mathrm{C}$ 하 강하였다. $2 \mathrm{~W}$ 의 시작온도는 $43.2 \pm 0.48^{\circ} \mathrm{C}$ 였고, 60 초 경과 후 $35.7 \pm 0.11^{\circ} \mathrm{C}$ 로 $7.1 \pm 0.23^{\circ} \mathrm{C}$ 하강하였다. 2.5 $\mathrm{W}$ 의 경우 시작온도는 $44.5 \pm 1.25^{\circ} \mathrm{C}$ 였으며, 60 초 경과 후 $35.1 \pm 0.32^{\circ} \mathrm{C}$ 로 $8.7 \pm 0.96^{\circ} \mathrm{C}$ 하강하였다. $\mathrm{B} 808$ 과
마찬가지로 출력이 높아서 시작온도가 높을수록 하강 온도폭이 증가하는 것을 확인하였으며 B808보다 더 높 은 온도 변화를 나타내었다.

B808의 경우, $1 \mathrm{~W}$ vs $1.5 \mathrm{~W}, 1 \mathrm{~W}$ vs $2 \mathrm{~W}, 1 \mathrm{~W}$ vs 2.5 $\mathrm{W}$ 를 비교했을 때 통계적으로 유의한 차이를 보였다 $(P>$ $0.05) \mathrm{P} 810$ 레이저의 경우에는 $1 \mathrm{~W}$ vs $2.5 \mathrm{~W}$ 를 비교했을 때 통계적으로 유의한 차이를 보였다 $(P>0.05)$.

5) Surface morphology change of disc by laser irradiation FE-SEM을 이용하여 diode laser 조사 전 후의 디스크 표면의 변화를 관찰하기 위해서 가장 온도의 변화가 많 았던 $2.5 \mathrm{~W}$ 조건의 P810를 조사한 디스크의 표면을 대 표로 관찰하였다. 디스크의 표면을 관찰한 결과, 디스크 표면에서 눈에 띨만한 특이한 변화는 발견할 수 없었다 (Fig. 3).

6) Sterilizing effect of Bison $808 \mathrm{~nm}$ Diode laser.

$\mathrm{RBM}, \mathrm{SLA}$ 처리를 한 디스크에 B808 조사 후, FE$\mathrm{SEM}$ 영상과 $\mathrm{EDS}$ 측정을 통하여 분석을 실시하였다. Fig. $4 \mathrm{~A}$ 와 Fig. $5 \mathrm{~A}$ 와 같이 표면처리만 한 경우, SLA의 표면이 조금 더 거칠어 진 것을 확인할 수 있었다. Fig. 4B와 Fig. $5 \mathrm{~B}$ 는 디스크에 표면처리를 한 뒤 박테리아를 도포한 결 과를 보여주고 있다. RBM 코팅 시 박테리아가 디스크 의 $52.36 \%$ 를 차지했고, SLA 코팅은 $40.28 \%$ 를 차지하여 $\mathrm{RBM}$ 코팅이 박테리아 도포에 더 효과적인 것을 확인하 였다. Fig. 4C, 4D와 Fig. 5C, 5D에서 레이저 출력량이 증 가함에 따라 박테리아 면적이 줄어드는 것을 확인하였으 며, $\mathrm{EDS}$ 측정 결과에서도 레이저 출력량이 높아짐에 따
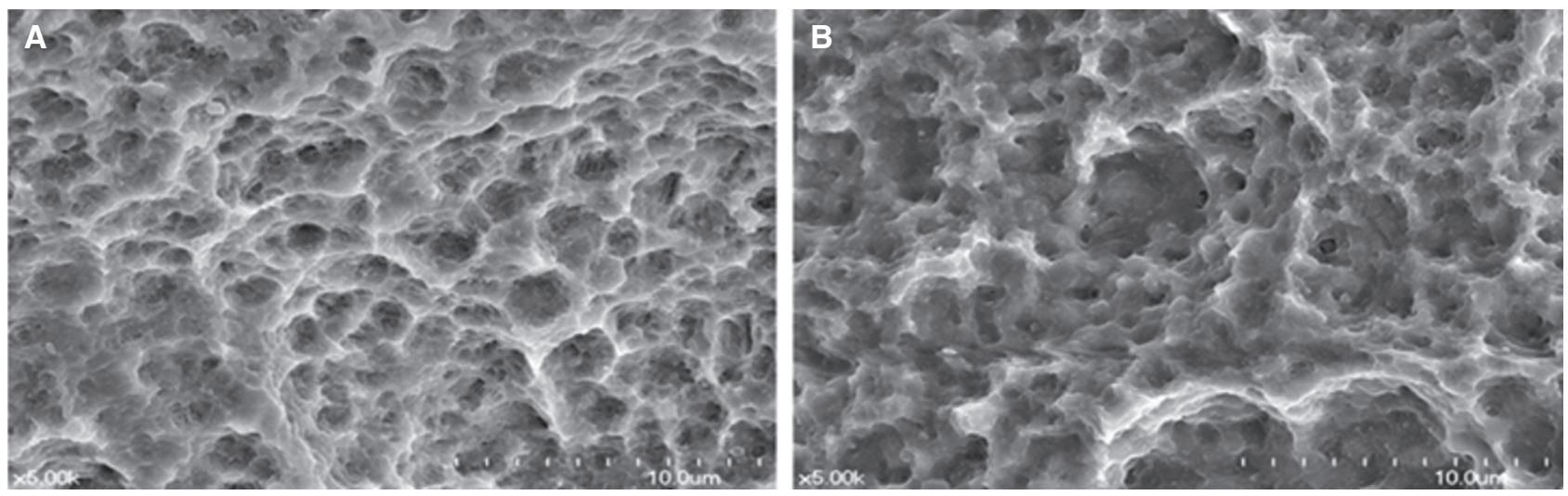

Fig. 3. Surface morphology change of disc. (A) Disc surface before laser irradiation, (B) Disc surface after P810 at $2.5 \mathrm{~W}$ power condition. $\times 5000$. 

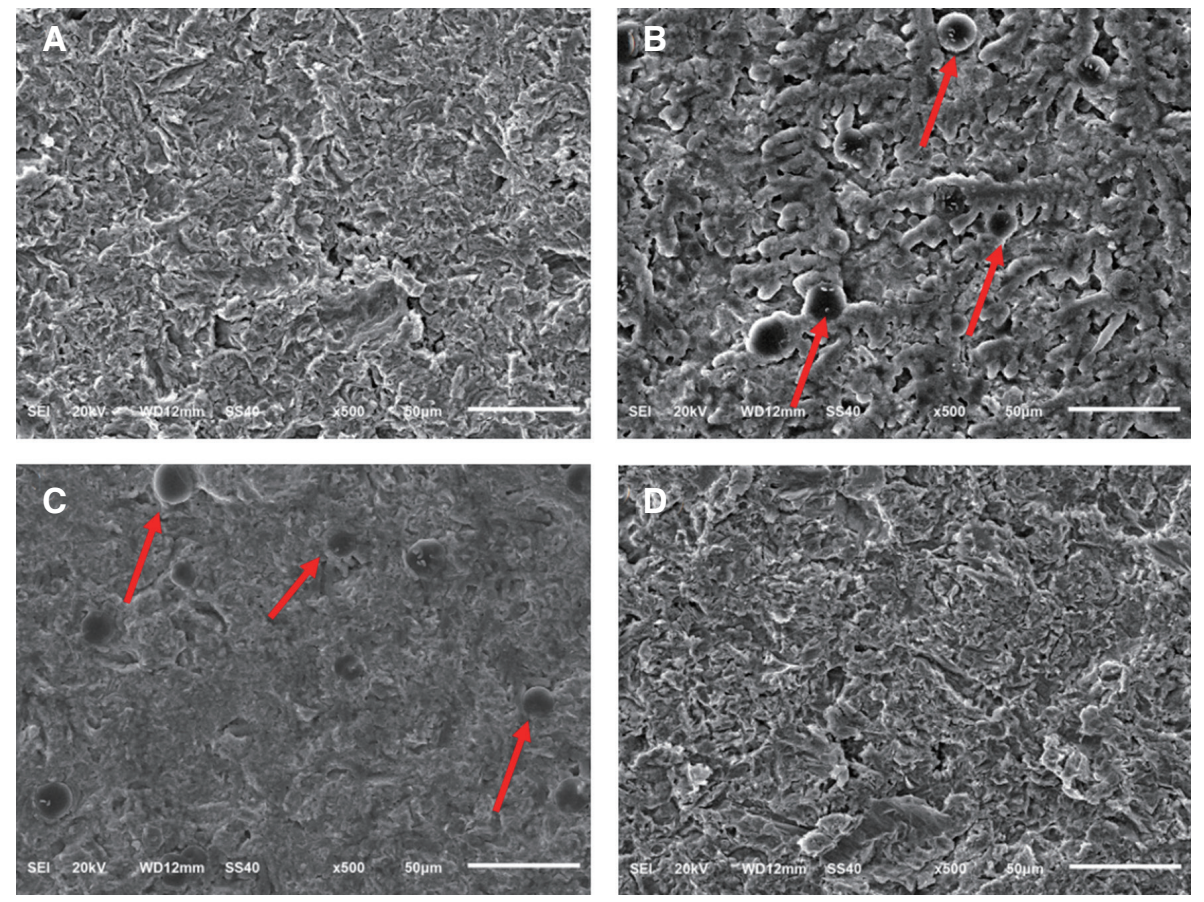

Fig. 4. Sterilizing effect of $B 808$ at RBM surface treatment titanium disc. The arrows indicate the locations of individually attached bacteria. (A) RBM treated titanium disc without bacteria. (B) RBM treated titanium disc with bacteria. (C) RBM treated titanium disc with bacteria after $0.5 \mathrm{~W}$ laser power for $30 \mathrm{~s}$ condition. (D) RBM treated titanium disc with bacteria after $3 \mathrm{~W}$ laser power for $30 \mathrm{~s}$ condition. $\times 500$.
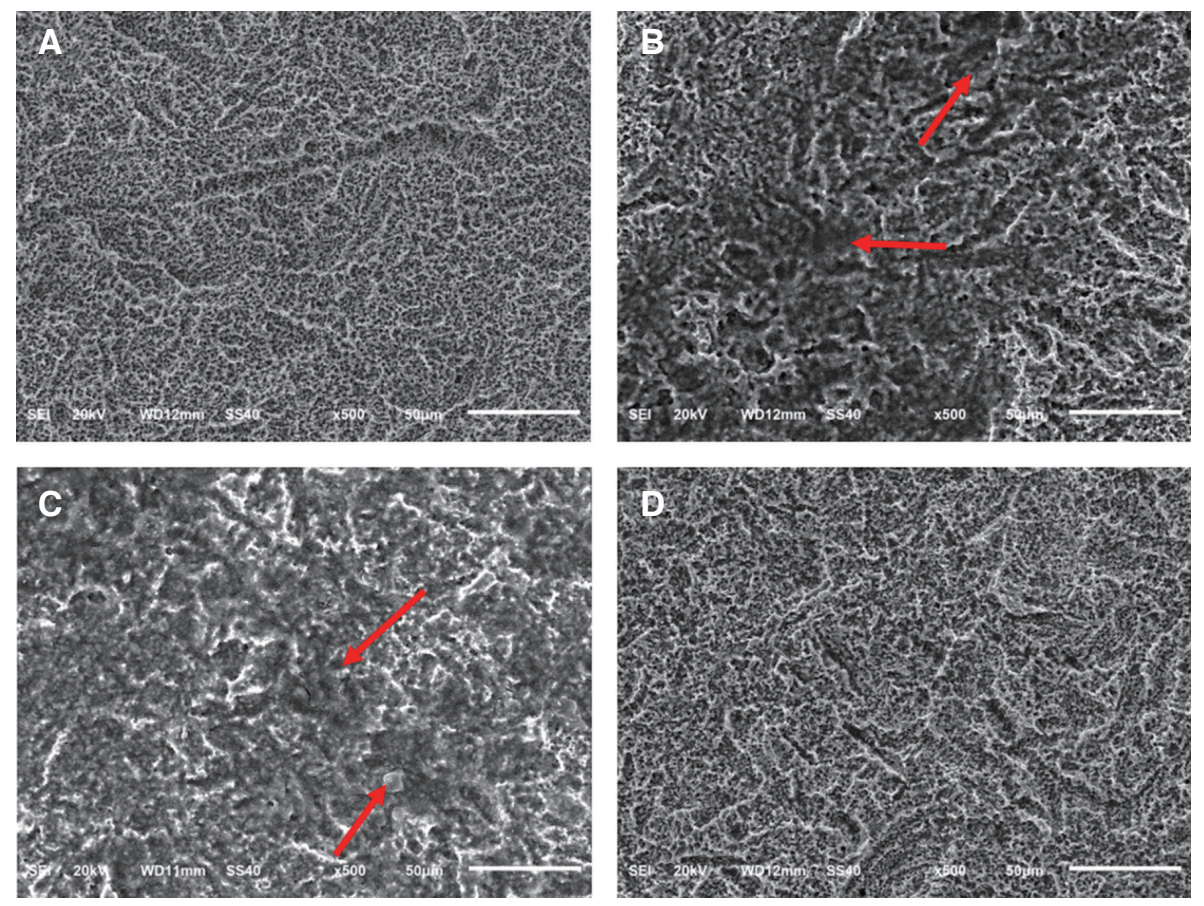

Fig. 5. Sterilizing effect of B808 at SLA surface treatment titanium disc. The arrows indicate the locations of individually attached bacteria. (A) SLA treated titanium disc without bacteria. (B) SLA treated titanium disc with bacteria. (C) SLA treated titanium disc with bacteria after $0.5 \mathrm{~W}$ laser power for $30 \mathrm{~s}$ condition. (D) SLA treated titanium disc with bacteria after $3 \mathrm{~W}$ laser power for $30 \mathrm{~s}$ condition. $\times 500$. 


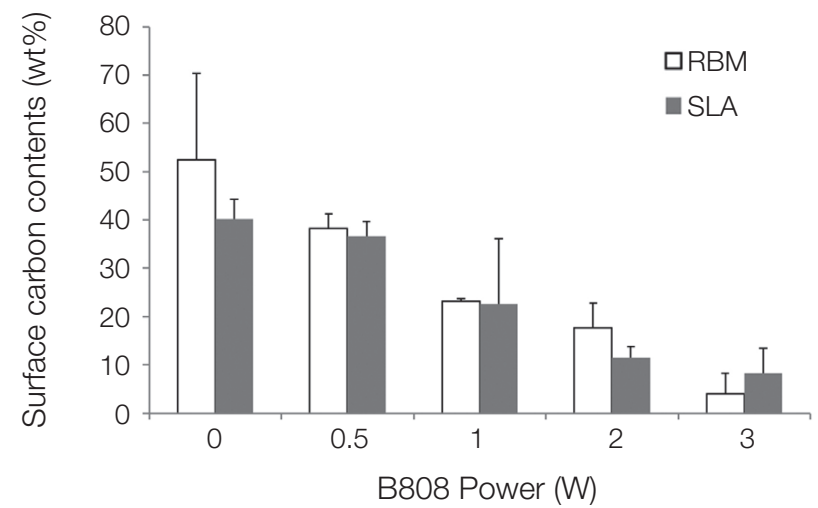

Fig. 6. Carbon contents of titanium disk surface according to power of B808. SLA coating, $\square$; RBM coating, $\square$.

라 디스크 표면의 탄소함유량이 줄어드는 것을 확인할 수 있었다(Fig. 6). ${ }^{20}$ 또한, RBM과 SLA 코팅을 한 디스크 표면은 레이저 조사 후에도 표면 상태의 변화가 없음을 FE-SEM 촬영을 통해 확인하였다. ${ }^{21,22}$

\section{고찰}

세균의 감염으로 인한 임플란트 주위염 및 임플란트 주위 점막염은 임플란트 식립 후, 실패의 주요한 원인 중 하나이다. ${ }^{23,24}$ 따라서 임플란트 주위의 살균을 통한 임플 란트 주위염의 개선 및 치료는 중요한 치과 치료과정이 라 할 수 있다. 본 연구에서는, 레이저 장치를 통한 임플 란트 주위염 치료의 효과를 확인하기 위해 B808을 디스 크에 60 초간 조사한 결과, 출력이 증가함에 따라 disc의 표면 온도도 증가하는 것을 확인하였다. 디스크 표면의 초기 온도상승속도를 측정한 결과, 대체적으로 출력이 증가함에 따라 온도 상승 속도가 커지는 것을 확인하였 다. 초기 5 초간 온도 상승률은 $1 \mathrm{~W}$ 조건과, $1.5,2,2.5 \mathrm{~W}$ 조건을 비교하였을 때, $95 \%$ 신뢰 범위에서 유의한 차이 를 보였으나, 다른 조건에서는 유의한 차이를 보이지 않 았다. 또한 $2.5 \mathrm{~W}$ 조건에서의 초기 온도 상승률은 $2 \mathrm{~W}$ 보 다 감소하였다. 레이저 조사 전 후, 온도차이는 $1.5 \mathrm{~W}$ 와 $2 \mathrm{~W}$ 조건에서 비교 시 유의한 차이를 보이지 않았다. 또 한 60 초간 레이저 조사한 뒤 60 초간 공랭 후 측정한 디스 크 표면 온도변화 분석결과, 출력이 높아짐에 따라 온도 의 변화폭도 증가하였으며, 초기 5 초간의 온도하강속도 역시 대체적으로 증가하는 것을 확인하였다. 하지만 대 부분의 조건에서 $95 \%$ 신뢰 범위에서 유의한 차이를 보이
지 않았으며, $1 \mathrm{~W}$ 조건에서 다른 조건들과 유의한 차이를 나타내었다.

P810을 디스크에 60초간 조사한 결과 역시 마찬가지 로 출력이 증가함에 따라 온도가 상승 하였다. 모든 조 건에서 B808보다 높은 온도 값을 보이는 것을 확인하였 다. $2.5 \mathrm{~W}$ 조건에서 60 초간 레이저를 조사한 후 측정한 disc 표면의 최고 온도는 $\mathrm{B} 808$ 이 $37.8^{\circ} \mathrm{C}, \mathrm{P} 810$ 이 $44.6^{\circ} \mathrm{C}$ 로 높은 차이를 보였다. 또한, 초기 5 초간 온도 상승률에 있어서도 두 장치의 최고 속도를 비교하였을 때, B808은 $0.42^{\circ} \mathrm{C} / \mathrm{sec}, \mathrm{P} 8101.32^{\circ} \mathrm{C} / \mathrm{sec}$ 로 P810가 약 3배 빠른 속 도로 온도가 상승하는 것을 알 수 있었다. 초기 5 초간 온 도 상승률은 $1 \mathrm{~W}$ 조건과 $2.5 \mathrm{~W}$ 조건을 제외하고, 모든 조 건에서 각각 비교하였을 때, $95 \%$ 신뢰 범위에서 유의한 차이를 보였다. 또한, $2 \mathrm{~W}$ 조건에서 초기 방출속도가 잠 시 감소하는 것으로 나타났다. 레이저 조사 전 후, 온도 차이는 모든 조건에서 유의한 차이를 나타내었다. 또한, P810을 디스크에 60초간 레이저 조사 후, 60초간 공랭 후 측정한 디스크 표면 온도변화의 분석결과, B808과 마 찬가지로 출력이 증가함에 따라 60 초후 온도 변화폭이 증가 하였으며 P810이 B808보다 더 많은 온도 변화를 보이는 것을 확인하였다. 초기 5 초간 온도 하강 변화율 은 95\% 신뢰 범위에서 유의한 차이를 보이지 않았다. 온 도차이는 $1 \mathrm{~W}$ 조건과 $2.5 \mathrm{~W}$ 조건을 제외하고, 유의한 차 이를 보이지 않았다. 하지만 모든 조건에서 B808 레이저 보다는 높은 온도변화를 보였다.

두 가지 장비의 레이저 조사 전 후 디스크의 표면 상태 를 확인한 결과, FE-SEM 촬영 이미지상에서는 두드러진 변화를 관찰할 수 없었으며 이는 참고 문헌과 동일한 결 
과를 나타내었다. ${ }^{14}$

$\mathrm{B} 808$ 의 살균 효과를 확인한 결과, 모든 실험 조건에서 출력이 증가할수록 박테리아 생존률은 감소하였다.

결론적으로 각 출력 조건에서 초기 온도 상승률, 하강 률 및 온도 변화량은 B808이 P810 보다 동일 출력에서 온도의 변화가 적었으며 살균 효과를 나타내므로 임상적 으로 유효한 온도 범위 내에서 주변 조직에 대한 영향을 적게 미치면서 임플란트 주위염 치료에 적용이 가능하리 라 판단된다.

\section{결론}

P810과 B808의 온도 상승 정도를 비교한 결과를 통하 여, 동일 조건에서 P810보다 B808의 온도상승률 및 하강 률이 낮았고 최대 상승 온도 역시 낮은 값을 가지는 것을 알 수 있었으며, B808의 살균효과를 확인하였다. 따라 서, 실제로 임상에 적용하는 경우 동일한 출력 조건에서 P810보다 더욱 안전하게 임상에 적용할 수 있을 것으로 사료된다. 하지만 B808가 실제 임플란트 주위염 치료에 적용하기 위해서는 보다 다양한 안전성 평가와 임상적 데이터를 바탕으로 새로운 장비에 대한 신뢰성을 확보하 여야 할 것이라 판단된다. 또한 추후 다양한 구내 박테리 아에 대한 레이저 장치의 살균 효과를 검증하기 위한 연 구가 더 필요할 것으로 사료된다.

\section{Acknowledgments}

본 연구는 산업통상자원부의 지원을 받아 실시하였습 니다(10047615).

\section{ORCID}

Jeong-Hwan Seol https://orcid.org/0000-0003-37194681

Jun Jae Lee https://orcid.org/0000-0002-5496-0168

Kee-Yeon Kum https://orcid.org/0000-0002-3032-3498

Jong-Ho Lee https://orcid.org/0000-0002-8843-545X

Young-Joon Lim https://orcid.org/0000-0003-2504-9671

\section{References}

1. Ishikawa I, Aoki A, Takasaki AA, Mizutani K,
Sasaki KM, Izumi Y. Application of lasers in periodontics: true innovation or myth? Periodontol 2000 2009;50:90-126.

2. Dörtbudak O, Haas R, Bernhart T, Mailath-Pokorny G. Lethal photosensitization for decontamination of implant surfaces in the treatment of periimplantitis. Clin Oral Implants Res 2001;12:104-8.

3. Schwarz F, Sculean A, Rothamel D, Schwenzer $\mathrm{K}$, Georg T, Becker J. Clinical evaluation of an Er:YAG laser for nonsurgical treatment of periimplantitis: a pilot study. Clin Oral Implants Res 2005;16:44-52.

4. Atieh MA, Alsabeeha NH, Faggion CM Jr, Duncan WJ. The frequency of peri-implant diseases: a systematic review and meta-analysis. J Periodontol 2013;84:1586-98.

5. Lindhe J, Meyle J; Group D of European Workshop on Periodontology. Peri-implant diseases: Consensus Report of the Sixth European Workshop on Periodontology. J Clin Periodontol 2008; 35:282-5.

6. Froum SJ, Rosen PS. A proposed classification for peri-implantitis. Int J Periodontics Restorative Dent 2012;32:533-40.

7. Esposito M, Grusovin MG, Kakisis I, Coulthard P, Worthington HV. Interventions for replacing missing teeth: treatment of peri implantitis. Cochrane Database Syst Rev 2008 Apr 16;(2):CD004970. doi: 10.1002/14651858.CD004970.pub3.

8. Ntrouka VI, Slot DE, Louropoulou A, Van der Weijden F. The effect of chemotherapeutic agents on contaminated titanium surfaces: a systematic review. Clin Oral Implants Res 2011;22:681-90.

9. Kotsovilis S, Karoussis IK, Trianti M, Fourmousis I. Therapy of peri-implantitis: a systematic review. J Clin Periodontol 2008;35:621-9.

10. Tosun E, Tasar F, Strauss R, Kivanc DG, Ungor C. Comparative evaluation of antimicrobial effects of Er:YAG, diode, and CO2 lasers on titanium discs: and experimental study. J Oral Maxillofac Surg 2012;70:1064-9.

11. Stubinger S, Etter C, Miskiewicz M, Homann F, Saldamli B, Wieland M, Sader R. Surface alterations of polished and sandblasted and acid-etched titanium implants after Er:YAG, carbon dioxide, 
and diode laser irradiation. Int J Oral Maxillofac Implants 2010;25:104-11.

12. Park JH, Heo SJ, Koak JY, Kim SK, Han CH, Lee JH. Effects of laser irradiation on machined and anodized titanium disks. Int J Oral Maxillofac Implants 2012;27:265-72.

13. Kreisler M, Al Haj H, Götz H, Duschner H, d'Hoedt B. Effect of simulated $\mathrm{CO}_{2}$ and GaAlAs laser surface decontamination on temperature changes in Ti-Plasma sprayed dental implants. Lasers Surg Med 2002;30:233-9.

14. Kim JH, Choi BK, Choi SH, Cho KS, Chai JK, Kim CK. Ribotyping of Porphyromonas Gingivalis isolated from rapidly progressive periodontitis patients. J Korean Acad Periodontol 1999;29:963-77.

15. Kim SY, Woo DH, Lee MA, Kim JS, Lee JH, Jeong $\mathrm{SH}$. Red fluorescence of oral bacteria interacting with Porphyromonas gingivalis. J Korean Acad Oral Health 2017;41:22-7.

16. Peck SY, Ku Y, Rhyu IC, Hahm BD, Han SB, Choi SM, Chung CP. The frequency of detecting Prevotella intermedia and Prevotella nigrescens in Korean adult periodontitis patients. J Korean Acad Periodontol 2000;30:419-27.

17. Romanos GE, Everts H, Nentwig GH. Effects of diode and Nd:YAG laser irradiation of titanium discs: a scanning electron microscope examination. J Periodontol 2000;71:810-5.

18. Slater SC, Voige WH, Dennis DE. Cloning and expression in Escherichia coli of the Alcaligenes eutrophus H16 poly-beta-hydroxybutyrate biosynthetic pathway. J Bacteriol 1988;170:4431-6.

19. McDaniel TK, Kaper JB. A cloned pathogenicity island from enteropathogenic Escherichia coli confers the attaching and effacing phenotype on E. coli K 12. Mol Microbiol 1997;23:399-407.

20. Cooper GM. The cell: a molecular approach. 4th ed. Sunderland; Sinauer Associates, Inc; 2007. p 4373.

21. Lee KJ, Lee JH, Kum KY, Lim YJ. Laser therapy in peri-implantitis treatment: literature review. J Dent Rehabil Appl Sci 2015;31:340-8.

22. Kreisler M, Kohnen W, Marinello C, Götz H, Duschner H, Jansen B, D'Hoedt B. Bactericidal effect of the Er: YAG laser on dental implant sur- faces: an in vitro study. J Periodontol 2002;73:12928.

23. Koo PM, Lee DW. The diagnosis and treatment of peri-implantitis. J Dent Implant Res 2015;34:76-80.

24. Oh WS, Ryu JJ, Ji S. Microbiology of Peri-implantitis. J Dent Implant Res 2013;32:1-6. 


\title{
임플란트 주위염 치료용 diode laser의 파장 및 조사시간에 따른 온도 변화와 살균효과 분석
}

\author{
설정환 ${ }^{1}$, 이준재 ${ }^{1}$, 금기연 ${ }^{2}$, 이종호 ${ }^{3}$, 임영준 $^{*}$ \\ ${ }^{1}$ 서울대학교 치의학대학원 치과보철학교실 \\ ${ }^{2}$ 서울대학교 치과병원 치과보존학교실 \\ ${ }^{3}$ 서울대학교 치과병원 구강악안면외과
}

목적: 본 연구에서는 새로 개발된 다이오드 레이저 제품을 이용하여 레이저 파워에 따른 온도변화와 박테리아 멸균 비교 실험을 통하여 기존 제품과의 임플란트 주위염치료에 대한 효과를 비교 실험하였다.

연구 재료 및 방법: $808 \mathrm{~nm}$ Diode laser와 $810 \mathrm{~nm}$ Diode laser를 사용하여 디스크에 레이저를 60초간 조사하였으며, 출 력은 1 - $2.5 \mathrm{~W}$ 로 설정하였다. 온도측정 모듈과 온도측정 프로그램을 이용하여 disc 표면온도변화를 측정하였다. 또한, SLA, RBM이 코팅된 disc에 bacteria 도포 후, $808 \mathrm{~nm}$ Diode laser를 30초간 조사하였으며, 출력은 0.5 - 3 W로 설정하였다. 결과: $808 \mathrm{~nm}, 810 \mathrm{~nm}$ 두 장치 모두 출력이 증가함에 따라 온도 상승폭은 증가하였다. 모든 조건에서 $810 \mathrm{~nm}$ laser를 조사하였을 때 초기온도상승속도, 하강속도 및 전후의 온도변화량은 $808 \mathrm{~nm}$ laser 보다 높았다. 레이저 조사 후 티타늄 디스크 표면의 변화는 두 레이저 모두에서 관찰되지 않았다. Bacteria가 도포된 디스크에 $808 \mathrm{~nm}$ laser를 조사한 결과, 출 력이 증가 함에 따라 살균효과가 증가하는 것을 확인하였다.

결론: Diode laser를 임상에 적용하는 경우, 동일한 출력에서 온도의 변동폭이 적고 최대 상승온도가 낮은 $808 \mathrm{~nm}$ laser 가 환자에 안전할 것으로 사료된다. 하지만 실제로 임상에 적용하기 위해서는 보다 다양한 안전성평가를 실시하여 장비 에 대한 신뢰성을 확보하여야 할 것이다.

(구강회복응용과학지 2017;33(3):178-88)

주요어: 임플란트 주위염; 다이오드 레이저; 박테리아; 티타늄; 온도변화

*교신저자: 임영준

(03080) 서울시 종로구 대학로 101 연건동 서울대학교 치과병원

Tel: 02-2072-2940 | Fax: 02-2072-3860 | E-mail: limdds@snu.ac. kr

접수일: 2017년 4월 24일 | 수정일: 2017년 7월 18일 | 채택일: 2017년 7월 22일 